\title{
簡易型高所打音検査装置の音響収集性能の改善
}

\section{Improvement of Sound Acquisition Device of Simple Impact Acoustic Apparatus for Testing at High Place}

\author{
学 徳臣 佐衣子（熊大院） 正 森 和也（熊大院） 学 矢野 恕雅（熊大院）
}

Saeko TOKUOMI, Graduate School of Kumamoto University, 2-39-1 Kurokami, Chuo-ku, Kumamoto Kazuya MORI, Yukimasa YANO

Key Words: Nondestructive Testing, Concrete Structure, Impact Acoustic Testing, Sound Acquisition

\section{1. 緒言}

著者らは，コンクリートや鉄製の構造物の高所を検査する ための壁面登はん型検査装置 ${ }^{(1)}$ や Fig. 1 に示すような簡易型 高所打音検查装置 ${ }^{(2)}$ の開発をおこなっている。これらの検査 装置で採用している検査方法は打音検査法である。検査対象 をハンマーでたたいて，衝撃音をマイクロフォンで収集し， その音響信号に基づいて試験あるいは検查をおこなう。

著者らが過去に開発した遠隔操作可能な打音検査装置は, ハンマーを押し出すための機械音がノイズとなり，検査の精 度を低下させていた ${ }^{(1)}$.今回，音響収集用のマイクロフォン の支持方法を改良することによって，ノイズの大幅な低減を 実現した.

\section{2. 打音検査装置}

Fig.2 に今回開発した打音検査装置示している。打音検査 装置は打撃部と音響収集部からなる．打撃部の仕組みは，従 来と同じである．スプリングをチェーン駆動によって圧縮, 開放することによって，ハンマーを押し出す，ハンマーの質 量は $162 \mathrm{~g}$ で，押し出し速さは約 $2 \mathrm{~m} / \mathrm{s}$ である.

音響収集部は，打撃点を取り囲むように，打撃点から等 距離に 4 個のマイクロフォンを配置している. マイロフォ ンで収集された音響信号は重ね合わせられ，打撃装置及び 外部からのノイズは低減される.

今回の改良点は，マイクロフォンの支持方法と，マイクロ フォンの背面からの音響の低減である。これまでマイクロフ オンを固定していたアルミ板を振動減衰材料（内外ゴム侏) ネナイト PG-60L) に置き換えた. 支持部は, 断面が一辺 $10 \mathrm{~mm}$ の正方形で，長さを $20 \mathrm{~mm}$ とした．また，マイクロフォンの 背面を音響反射板で覆い, 機械音の背面からの侵入を低下さ せた。

$$
\text { 3. 実験 }
$$

改良による計測信号の変化とその結果精度に及ぼす効果 について実験に基づく検証をおこなった. Fig. 3 に試験片と

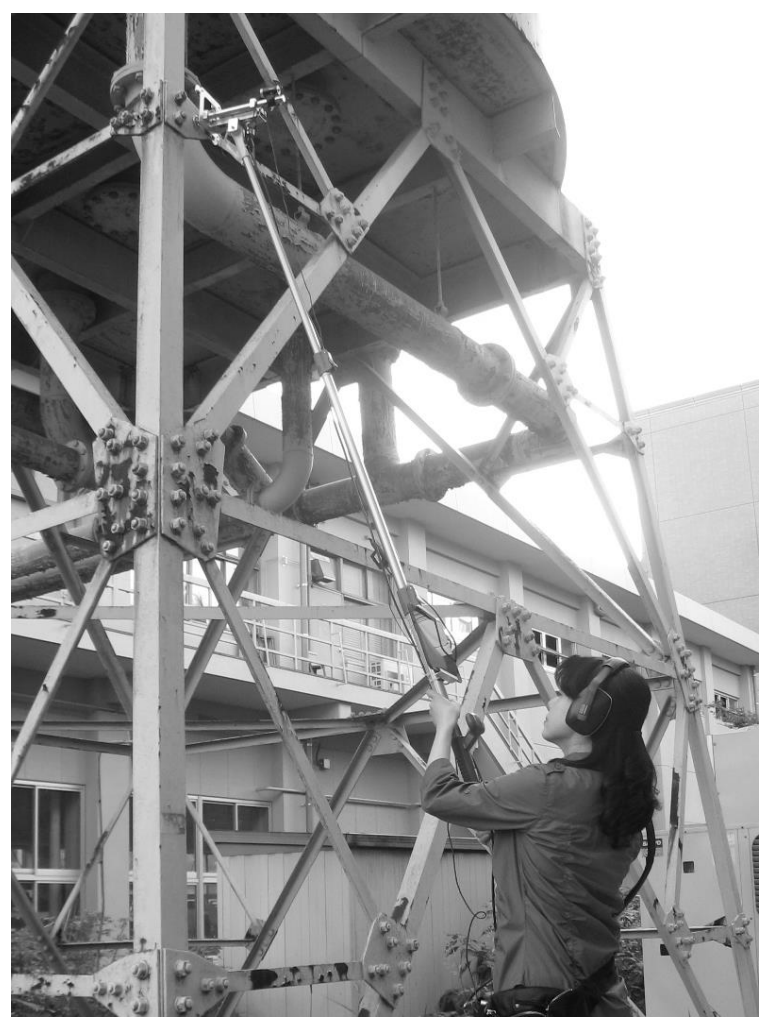

Fig. 1 Simple impact acoustic apparatus for testing at high place

試験方法を示している．試験片は直径 $200 \mathrm{~mm}$ の円盤状欠陥 を有するコンクリート試験体で，深さは $25 \mathrm{~mm} ， 50 \mathrm{~mm}$, $100 \mathrm{~mm}$ の 3 種類と, 欠陥のないコンクリート試験体である.

Fig. 4 と Fig. 5 は, 従来の打音検査装置で深さ $25 \mathrm{~mm}$ の欠 陥を有する試験体を打撃したときの音響信号とその周波数 スペクトルである. 低い周波数の大きな信号と高い周波数の 成分が混在していることがわかる。低い周波数の信号は機械

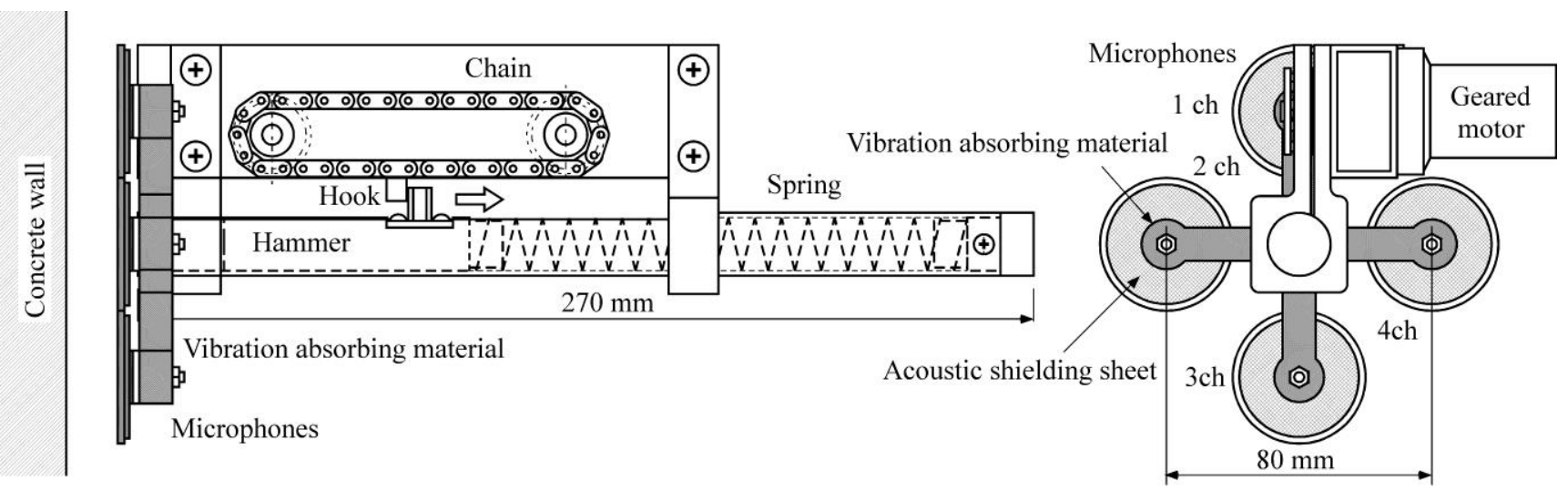

Fig. 2 The new impact acoustic apparatus 


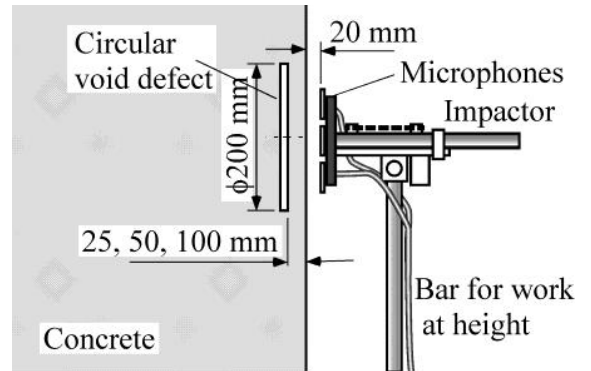

Fig. 3 Specimen and experiment method

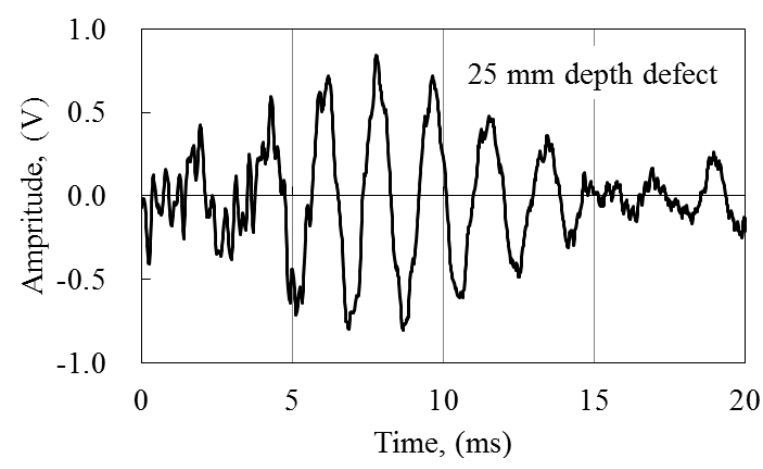

Fig. 4 Impact acoustic signals by the past apparatus

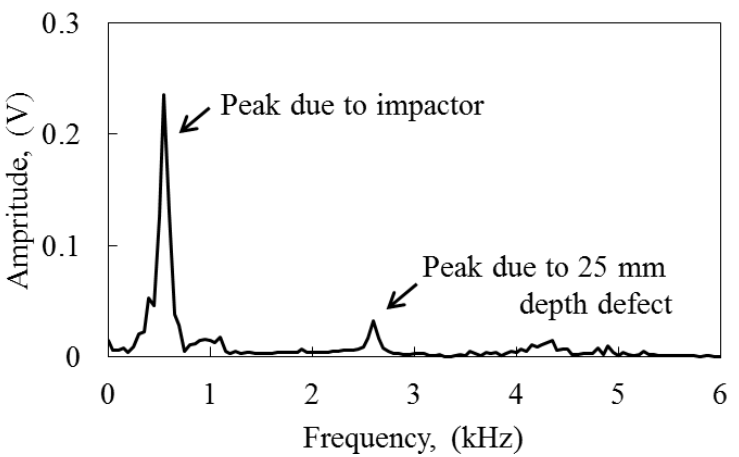

Fig. 5 The frequency spectrum of Fig. 4 (the past apparatus)

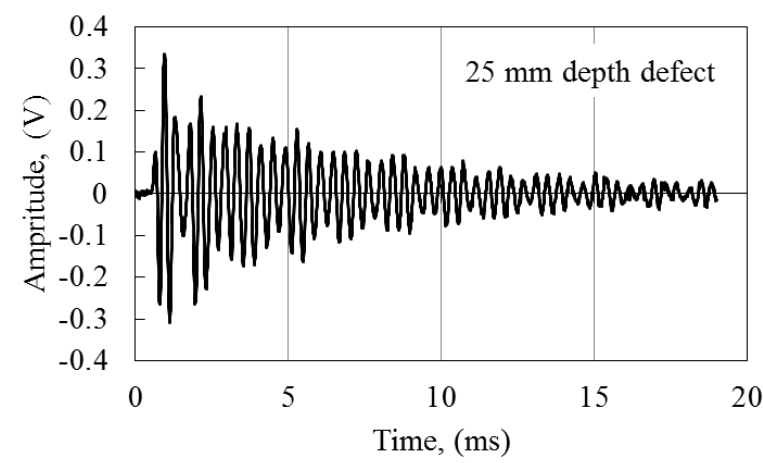

Fig. 6 Impact acoustic signals by the new apparatus

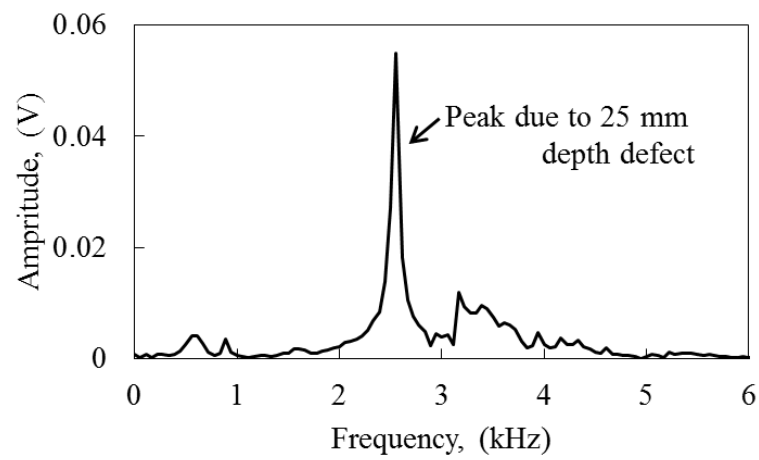

Fig. 7 The frequency spectrum of Fig. 6 (the new apparatus)

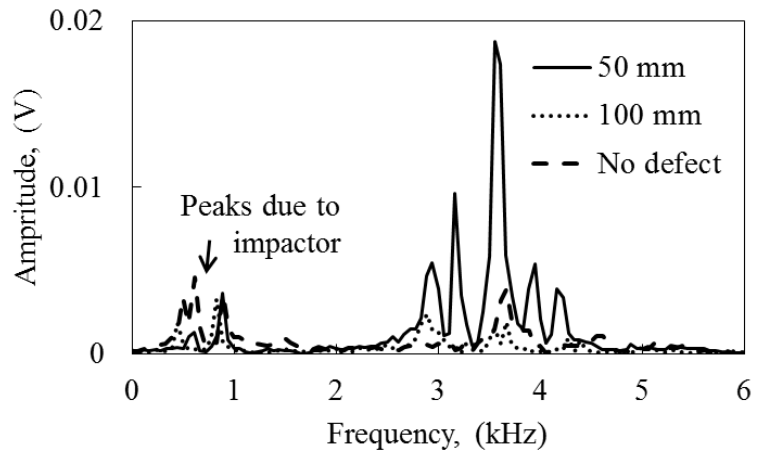

Fig. 8 The frequency spectrum of $50 \mathrm{~mm}, 100 \mathrm{~mm}$ and no defect

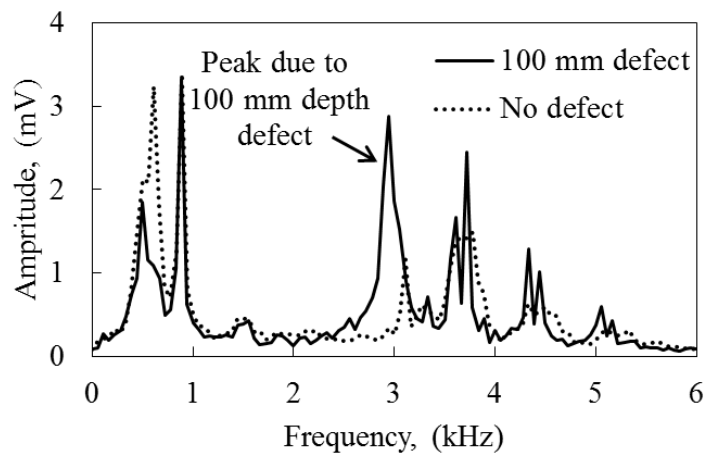

Fig. 9 The averaged spectrums of $100 \mathrm{~mm}$ and no defect

振動によるノイズである.

Fig. 6 と Fig. 7 は，改良した打音検査装置を用いて同じ試 験体（深さ $25 \mathrm{~mm}$ の欠陥）を打撃したときの音響信号とその 周波数スペクトルである. 機械的ノイズが大幅に低減し，欠 陥による信号が明確に現れていることがわかる。

Fig. 8 は，深さ $50 \mathrm{~mm}, 100 \mathrm{~mm}$ に欠陥を有する試験体と 欠陥のない試験体の打撃音の周波数スペクトルである。こ の図から深さ $50 \mathrm{~mm}$ に位置する欠陥の検出は可能であるこ とがわかる。しかしながら，一回の打撃音に基づく試験で は, 深さ $100 \mathrm{~mm}$ の欠陥の検出は難しい.

そこで，10 回の試験によって得られた周波数スペクトル を平均したものの比較を Fig. 9 に示す.この図から分かる ように，複数回の結果を平均化することによって深さ $100 \mathrm{~mm}$ に位置する欠陥も検出が可能である.

以上の結果から, 直径 $200 \mathrm{~mm}$ の人工欠陥の場合, 深さ $100 \mathrm{~mm}$ 程度の位置までは検出可能である。

\section{4. 結言}

打音検査装置のマイクロフォンの支持方法をアルミ板か ら振動減衰材料に変更することによって，音響収集性能の 改善をおこなった。その結果，これまで検出が困難であっ た, 深さ $50 \mathrm{~mm}$ に位置する直径 $200 \mathrm{~mm}$ の円盤状欠陥が検出可 能になった。 また，複数回の試験を行うことによって，深 さ $100 \mathrm{~mm}$ に位置する直径 $200 \mathrm{~mm}$ の円盤状欠陥も検出可能に なった。

\section{謝 辞}

本研究は独立行政法人科学振興機構の研究成果最適展開 支援プログラムA-Step の支援を受けた。ここに，感謝の意 を表する。

\section{文 献}

1）徳臣佐衣子, 森和也, 矢野怒雅, 日本機械学会鹿児島地方講 演会講演論文集，No. 138-3 (2013),pp. 199-200.

2) 徳臣佐衣子, 森和也, 矢野恕雅, 日本材料学会信頼性・破壊 力学合同シンポジウム講演論文集, (2013),pp. 173-177. 